\title{
Kordiimonas gwangyangensis gen. nov., sp. nov., a marine bacterium isolated from marine sediments that forms a distinct phyletic lineage (Kordiimonadales ord. nov.) in the 'Alphaproteobacteria'
}

\author{
Kae Kyoung Kwon, Hee-Soon Lee, Sung Hyun Yang and Sang-Jin Kim
}

Correspondence

Sang-Jin Kim

s-jkim@kordi.re.kr
Marine Biotechnology Research Centre, Korea Ocean Research and Development Institute, Ansan, PO Box 29, 425-600, Republic of Korea

\begin{abstract}
A marine bacterium, designated strain $\mathrm{GW} 14-5^{\top}$, capable of degrading high-molecular-mass polycyclic aromatic hydrocarbons was isolated from the sediments of Gwangyang Bay, Republic of Korea, after enrichment culture for 2 years with a mixture of benzo[a]pyrene and pyrene. Phylogenetic analysis based on 16S rRNA gene sequences indicated that the isolate forms a phyletic lineage that is distinct from the seven known orders within the 'Alphaproteobacteria'. 16S rRNA gene sequence similarity of strain $\mathrm{GW} 14-5^{\top}$ to all recognized bacterial species was not greater than $92 \%$. The dominant fatty acids of the isolate were $\mathrm{i}-17: 1(46 \cdot 2 \%), \mathrm{i}-15: 0(15 \cdot 1 \%)$ and $\mathrm{i}-17: 0(12 \cdot 6 \%)$. The major respiratory quinone was MK-5, and the DNA G +C content was $39.3 \mathrm{~mol} \%$. Cells of strain GW $14-5^{\top}$ were Gram-negative, motile, catalase-positive, oxidase-positive and weakly halophilic. Glucose, $N$-acetylglucosamine and maltose were utilized as sole carbon sources. The strain was positive for $\beta$-glucosidase activity. Optimal growth of strain $\mathrm{GW} 14-5^{\top}$ was at $\mathrm{pH} 7 \cdot 0$ and $37-40^{\circ} \mathrm{C}$ and required the presence of $2 \%(\mathrm{w} / \mathrm{v}) \mathrm{NaCl}$. On the basis of this evidence, strain $\mathrm{GW} 14-5^{\top}$ represents a novel genus and species in the 'Alphaproteobacteria' for which the name Kordiimonas gwangyangensis gen. nov., sp. nov. is proposed. The novel order Kordiimonadales is proposed for the distinct phyletic line represented by the genus Kordiimonas. The type strain is GW $14-5^{\top}\left(=\operatorname{KCCM~} 42021^{\top}=\mathrm{JCM} 12864^{\top}\right)$.
\end{abstract}

The 'Alphaproteobacteria' is one of the five classes of the phylum Proteobacteria (Garrity \& Holt, 2001). The second edition of Bergey's Manual of Systematic Bacteriology proposed that the class 'Alphaproteobacteria' should be divided into six orders: Caulobacterales, 'Rhizobiales', 'Rhodobacterales', Rhodospirillales, Rickettsiales and 'Sphingomonadales' (Garrity \& Holt, 2001). In the last few years, 24 new genera, and the novel order 'Parvularculales', have been reported in the 'Alphaproteobacteria' [Cho \& Giovannoni, 2003; refer also to the NCBI taxonomy homepage (http://www.ncbi.nlm. nih.gov/Taxonomy/Browser/wwwtax.cgi) and articles in this journal (http://ijs.sgmjournals.org)]. More than half of these new genera were isolated from marine environments, and most members could survive in oligotrophic environments.

In the present study, the taxonomic identification of a novel marine bacterium, strain GW $14-5^{\mathrm{T}}$, belonging to the

Published online ahead of print on 13 May 2005 as DOI 10.1099/ ijs.0.63684-0.

Abbreviations: $\mathrm{BaP}$, benzo[a]pyrene; $\mathrm{PAH}$, polycyclic aromatic hydrocarbon.

The GenBank/EMBL/DDBJ accession number for the 16S rRNA gene sequence of strain $\mathrm{GW} 14-5^{\top}$ is $\mathrm{AY} 682384$.
'Alphaproteobacteria' is described; on the basis of these results, the strain is considered to represent a novel species and genus, Kordiimonas gwangyangensis gen. nov., sp. nov.

Strain GW $14-5^{\mathrm{T}}$ was isolated from marine sediments collected in the Gwangyang Bay of the South Sea, Republic of Korea. About $1 \mathrm{~g}$ sediment was enriched with 100 p.p.m. each of pyrene and benzo[a]pyrene ( $\mathrm{BaP})$ in $\mathrm{MM} 2$ liquid medium [18 mM $\left(\mathrm{NH}_{4}\right)_{2} \mathrm{SO}_{4}, 1 \mu \mathrm{M} \quad \mathrm{FeSO}_{4} .7 \mathrm{H}_{2} \mathrm{O}$ and $100 \mu \mathrm{l} 1 \mathrm{M} \mathrm{KH} \mathrm{KH}_{2} \mathrm{PO}_{4} / \mathrm{Na}_{2} \mathrm{HPO}_{4}$ buffer solution in 1 litre of aged sea water, $\mathrm{pH} 7 \cdot 2$ ] for 2 years (a long-term enrichment method) at a temperature of $10-30{ }^{\circ} \mathrm{C}$. Then, $100 \mu \mathrm{l}$ slurry was plated onto marine agar 2216 (MA; Difco) after serial dilution. A tiny, translucent creamy white colony with morphology different from that of the other colonies growing on this medium was isolated and designated GW14-5 ${ }^{\mathrm{T}}$. Strain GW14-5 ${ }^{\mathrm{T}}$ was cultivated for 2-3 days at $30^{\circ} \mathrm{C}$ on $\mathrm{MA}$ for morphological and biochemical characterization.

The degradation rate of BaP by strain GW14- $5^{\mathrm{T}}$ was determined by the fluorimetry method (Zhang et al., 2004). Approximately 40 p.p.b. BaP and 1\% 2-hydroxypropyl$\beta$-cyclodextrin were solubilized in MM2 liquid medium, 


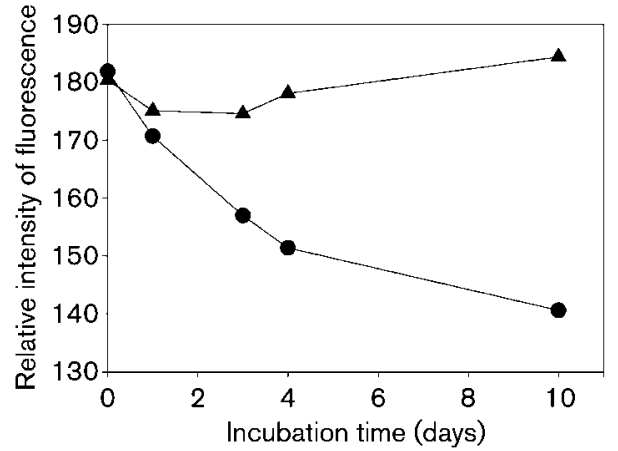

Fig. 1. Rate of degradation of benzo[a]pyrene $(\mathrm{BaP})$ by strain GW $14-5^{\top}$. The degradation rate was determined by the fluorimetry method (excitation at $293 \mathrm{~nm}$, emission at $406 \mathrm{~nm}$ ). The $y$-axis represents the relative intensity of fluorescence, which was measured depending upon the concentration of remaining $\mathrm{BaP}(180=40$ p.p.b. BaP). $\boldsymbol{\Delta}$, Uninoculated control; $\boldsymbol{\bullet}$, microcosm with strain $\mathrm{GW} 14-5^{\top}$.

and strain GW $14-5^{\mathrm{T}}$ was inoculated into this mixture. The relative intensity of fluorescence (excitation at $293 \mathrm{~nm}$, emission at $406 \mathrm{~nm}$ ) was measured after 1, 3, 4 and 10 days incubation. The fluorescence of $\mathrm{BaP}$ in the culture medium was significantly decreased during the period of incubation compared with that of the non-inoculated control (Fig. 1). The degradation rates of six different mixed polycyclic aromatic hydrocarbons (PAHs) (fluorene, phenanthrene, anthracene, pyrene, chrysene and $\mathrm{BaP}$ ) were estimated using the GC method described by Sohn et al. (2004) with 5 p.p.m. of each $\mathrm{PAH}$ compound at $30^{\circ} \mathrm{C}$. Based on triplicate samples, the degradation rates of the compounds relative to that of the non-inoculated control were: fluorene, $42 \cdot 1 \pm 19 \cdot 2 \%$; phenanthrene, $20 \cdot 8 \pm 16 \cdot 7 \%$; anthracene, $13 \cdot 9 \pm 14 \cdot 3 \%$; pyrene, $18 \cdot 1 \pm 11 \cdot 2 \%$; and $\mathrm{BaP}, 28 \cdot 0 \pm$ $4 \cdot 8 \%$. Chrysene was not degraded within 1 week of incubation.

Unless stated otherwise, physiological characterization was conducted according to the methods of Sohn et al. (2004). The Gram reaction was determined using the Bio-Rad Gram-staining kit, and motility was determined with an optical microscope (Zeiss Axioplan) by the hanging drop technique (Skerman, 1967). Cell size and morphology after dehydration were examined with a scanning electron microscope (model S-4300; Hitachi) at $10 \mathrm{kV}$. Growth temperature was tested over the range $12-48{ }^{\circ} \mathrm{C}$ at $4{ }^{\circ} \mathrm{C}$ intervals in marine broth 2216 (MB; Difco) in a temperature gradient incubator (TVS126MA; Advantec). Bacterial suspensions for the physiological and biochemical characterizations using an API 20NE test (bioMérieux) and a Microlog GN2 plate (Biolog) were prepared in a $2 \%$ sea salt (Sigma) solution. The physiological, biochemical and morphological characteristics of strain GW14-5 $5^{\mathrm{T}}$ are given below and in Table 1.

The profile of cellular fatty acid methyl esters was determined according to the method of Bae et al. (2005). The dominant fatty acids in strain GW14-5 ${ }^{\mathrm{T}}$ were $\mathrm{i}-17: 1$ $(46 \cdot 2 \%)$, i-15:0 (15.1\%) and i-17:0 (12.6\%). Strain

Table 1. Phenotypic characteristics differentiating strain GW $14-5^{\top}$ from other members of the 'Alphaproteobacteria'

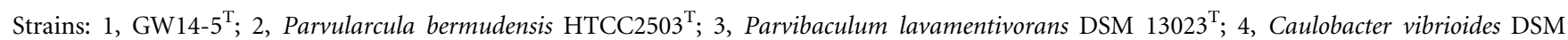
$9893^{\mathrm{T}}$; 5, Zymomonas mobilis ATCC $10988^{\mathrm{T}}$; 6, Paracoccus denitrificans ATCC $17741^{\mathrm{T}}$; 7, Rhizobium leguminosarum ATCC $10004^{\mathrm{T}}$; 8, Rickettsia prowazekii ATCC VR-142 ${ }^{\mathrm{T}}$; 9, Azospirillum lipoferum (characteristics represent all strains of Azospirillum lipoferum, including the type strain, ATCC $29707^{\mathrm{T}}$ ). Data are from Cho \& Giovannoni (2003), Jordan (1984), Kocur (1984), Krieg \& Döbereiner (1984), Poindexter (1989), Schleheck et al. (2004), Swings \& De Ley (1984) and Weiss \& Moulder (1984). +, Positive; -, negative; W, weakly positive; D, $11-89 \%$ of the strains are positive.

\begin{tabular}{|c|c|c|c|c|c|c|c|c|c|}
\hline Characteristic & 1 & 2 & 3 & 4 & 5 & 6 & 7 & 8 & 9 \\
\hline Cell size $(\mu \mathrm{m})$ & $\begin{array}{l}0 \cdot 25 \times \\
1 \cdot 3-1 \cdot 4\end{array}$ & $0 \cdot 8 \times 1 \cdot 0$ & $0 \cdot 2 \times 0 \cdot 8$ & $\begin{array}{c}0 \cdot 4-0 \cdot 6 \\
\times 1-2\end{array}$ & $\begin{array}{c}1 \cdot 0-1 \cdot 4 \times \\
2 \cdot 0-6 \cdot 0\end{array}$ & $\begin{array}{c}0 \cdot 5-0 \cdot 9 \times \\
0 \cdot 9-1 \cdot 2\end{array}$ & $\begin{array}{c}0 \cdot 5-0 \cdot 9 \times \\
1 \cdot 2-3 \cdot 0\end{array}$ & $\begin{array}{c}0 \cdot 3-0 \cdot 5 \times \\
0 \cdot 8-2 \cdot 0\end{array}$ & $\begin{array}{c}1 \cdot 0 \times \\
2 \cdot 1-3 \cdot 8\end{array}$ \\
\hline Colony size (mm) & $2-3$ & $0 \cdot 3-0 \cdot 8$ & & & $1-2$ & $2-3$ & $2-4$ & $0 \cdot 5-1 \cdot 5$ & \\
\hline $\begin{array}{l}\text { Growth temperature } \\
\left({ }^{\circ} \mathrm{C}\right)^{\star}\end{array}$ & $\begin{array}{c}17-44 \\
(37-41)\end{array}$ & $10-37(30)$ & & $\begin{array}{c}10-35 \\
(20-25)\end{array}$ & $15-38(30)$ & $5-37(30)$ & $4-38$ & $(35)$ & $(35-37)$ \\
\hline Growth $\mathrm{pH}^{\star}$ & $6-8 \cdot 5(7)$ & $6-8 \cdot 5(8)$ & & $6-9(7)$ & $3 \cdot 5-7 \cdot 5$ & (7) & $4 \cdot 5-9 \cdot 0$ & (7) & (7) \\
\hline $\begin{array}{l}\mathrm{NaCl} \text { range for growth } \\
(\%)^{*}\end{array}$ & $0 \cdot 5-4(2)$ & $0 \cdot 75-25(3)$ & & & $0-1$ & $0-5$ & & & $\leqslant 3$ \\
\hline $\begin{array}{l}\text { DNA G }+ \text { C content } \\
(\mathrm{mol} \%)\end{array}$ & $39 \cdot 3$ & $60 \cdot 8$ & $64 \cdot 5$ & $64-65$ & $47 \cdot 5-49 \cdot 5$ & $64-67$ & $59-63$ & $29-30$ & $69-70$ \\
\hline $\mathrm{O}_{2}$ requirement & + & + & + & + & - & - & + & + & - \\
\hline Oxidase/catalase activity & $+/ \mathrm{w}$ & $+1-$ & $+1+$ & & $-1+$ & $+1+$ & & & $+/ \mathrm{D}$ \\
\hline Nitrate reduction & - & & & & - & + & & & + \\
\hline
\end{tabular}

*Values in parentheses are the optimum range. 
Table 2. Cellular fatty acid composition (\%) of strain GW $14-5^{\top}$ and other members of the 'Alphaproteobacteria'

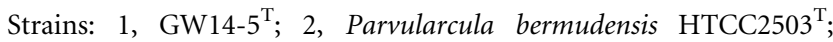
3, Parvibaculum lavamentivorans DSM $13023^{\mathrm{T}}$; 4, Novosphingobium pentaromativorans US6-1 ${ }^{\mathrm{T}}$; 5, Caulobacter vibrioides DSM $9893^{\mathrm{T}}$; 6, Paracoccus haeundensis KCCM $10460^{\mathrm{T}}$. Data are from Cho \& Giovannoni (2003), Lee et al. (2004), Poindexter (1989), Schleheck et al. (2004) and Sohn et al. (2004). No fatty acid composition data are available for members of the orders 'Rhizobiales', Rhodospirillales and Rickettsiales. Fatty acids that represented $<1 \cdot 0 \%$ were omitted.

\begin{tabular}{|c|c|c|c|c|c|c|}
\hline Fatty acid & 1 & 2 & 3 & 4 & 5 & 6 \\
\hline \multicolumn{7}{|l|}{ Saturated fatty acids } \\
\hline $10: 03-\mathrm{OH}$ & & & & & & $2 \cdot 1$ \\
\hline $12: 02-\mathrm{OH}$ & & $5 \cdot 2$ & & & & \\
\hline $14: 0$ & & $2 \cdot 9$ & & & & \\
\hline $\begin{array}{l}14: 02-\mathrm{OH} \text { and/or } \\
3-\mathrm{OH}\end{array}$ & & & $6 \cdot 3$ & $19 \cdot 7$ & $3 \cdot 9$ & $1 \cdot 5$ \\
\hline $15: 0$ & $1 \cdot 9$ & & & & & \\
\hline $\mathrm{i}-15: 0$ & $15 \cdot 1$ & & & & & \\
\hline $16: 0$ & $2 \cdot 7$ & $8 \cdot 6$ & $7 \cdot 7^{\star}$ & $3 \cdot 5^{\star}$ & $1 \cdot 1$ & \\
\hline $17: 0$ & $2 \cdot 0$ & & & & & \\
\hline $\mathrm{i}-17: 0$ & $12 \cdot 6$ & & & & & \\
\hline a-17:0 & $3 \cdot 5$ & & & & & \\
\hline $18: 0$ & & $4 \cdot 0$ & $9 \cdot 7$ & & $1 \cdot 3$ & $7 \cdot 8$ \\
\hline \multicolumn{7}{|l|}{ Unsaturated fatty acids } \\
\hline $12: 15 c$ & & & & & & $2 \cdot 0$ \\
\hline $\mathrm{i}-15: 1$ & $1 \cdot 4$ & & & & & \\
\hline $16: 1 \dagger$ & $1 \cdot 0$ & & $1 \cdot 4 \ddagger$ & $8 \cdot 9$ & & \\
\hline $\mathrm{i}-17: 1$ & $46 \cdot 2$ & & & $2 \cdot 0$ & & \\
\hline $18: 1 \S$ & $4 \cdot 2$ & $79 \cdot 3$ & $53 \cdot 211$ & $63 \cdot 9$ & $88 \cdot 8$ & $84 \cdot 5$ \\
\hline \multicolumn{7}{|l|}{ Remainder } \\
\hline $17: 0$ cyclo & $2 \cdot 6$ & & & & & \\
\hline 19:0 cyclo & & & $22 \cdot 79$ & & & \\
\hline Unidentified, etc. & $4 \cdot 5$ & & & & $3 \cdot 3$ & \\
\hline
\end{tabular}

${ }^{*}$ Includes 16:0 2-OH and/or 3-OH fatty acids.

$\dagger$ Contained the following fatty acids: $16: 1 \omega 5 c$ and/or $16: 1 \omega 7 c$. ¥Includes 16:1 3-OH fatty acids.

$\S$ Contained one or more of the following isomers: $18: 1 \omega 7 c$, $18: 1 \omega 5 c, 18: 1 \omega 9 t$ and/or $18: 1 \omega 12 t$ (cis and trans isomer are indicated by the suffixes $c$ and $t$, respectively).

IIIncludes 18:1 2-OH fatty acids.

Includes 19:0 2-OH fatty acids.

GW $14-5^{\mathrm{T}}$ also contained other straight-chain saturated fatty acids $(7 \cdot 3 \%)$, straight-chain unsaturated fatty acids $(5 \cdot 4 \%)$ and a cyclo-fatty acid $(2 \cdot 6 \%)$ (Table 2$)$.

The DNA G + C content was $39 \cdot 3$ mol\%, as determined by HPLC according to the method of Stackebrandt \& Liesack (1993), using a Symmetry reversed-phase C18 column (Waters). The major respiratory quinone was determined to be MK-5 by HPLC analysis according to the method of Collins (1985).
Genomic DNA extraction, PCR and sequencing of the 16S rRNA gene were conducted using the procedures described in Sohn et al. (2004). Preliminary sequence BLAST analysis and subsequent phylogenetic analyses indicated that strain GW $14-5^{\mathrm{T}}$ belonged to the 'Alphaproteobacteria' and that its closest recognized relative was Blastochloris sulfoviridis (92.0 \% 16S rRNA gene sequence similarity). However, 16S rRNA gene sequence similarity to $B$. sulfoviridis decreased to $89.3 \%$ after manual alignment and trimming of the sequence; hence this species was excluded from the phylogenetic tree (Fig. 2). Other species belonging to the 'Rhizobiales', such as Rhodobium orientis (91.5\%), Methylosinus trichosporium (91.4\%), Blastochloris viridis (90.9\%), Phyllobacterium myrsinacearum (90.8\%) and Parvibaculum lavamentivorans $(90.6 \%)$, as well as members of the 'Rhodobacterales', such as Paracoccus alkaliphilus (91.0\%) and Amaricoccus macauensis (90.4\%), also showed less than $92 \% 16 \mathrm{~S}$ rRNA gene sequence similarity. Therefore, the $16 \mathrm{~S}$ rRNA gene sequence of strain GW14-5 ${ }^{\mathrm{T}}$ was aligned with representative sequences, in the NCBI and RDP databases, of organisms that belong to the seven different orders of the 'Alphaproteobacteria' (Cho \& Giovannoni, 2003). The program PHYDIT version 3.2 (http://plaza.snu.ac.kr/ $\sim$ jchun/phydit/) was used for this analysis. Phylogenetic distances were calculated from the models of Jukes \& Cantor (1969), and the tree was constructed on the basis of the neighbour-joining method (Saitou \& Nei, 1987). The resultant phylogenetic tree indicates that strain GW14- $5^{\mathrm{T}}$ forms a phyletic line distinct from all seven orders of the 'Alphaproteobacteria' (Fig. 2). Furthermore, a specific relationship of the strain to these orders was not seen in the maximum-parsimony analysis. On the basis of the phylogenetic analysis, this novel strain appears to represent a novel order of the 'Alphaproteobacteria'.

Another interesting point is the phylogenetic status of Parvibaculum lavamentivorans. This strain was considered to be a member of the order 'Rhizobiales' (http://www.ncbi. nlm.nih.gov/Taxonomy/Browser/wwwtax.cgi). However, it forms a phyletic lineage with Parvularcula bermudensis in the present study (Fig. 2), indicating that Parvibaculum lavamentivorans should be reclassified as a member of the 'Parvularculales' or another new order instead of 'Rhizobiales'.

Strain GW $14-5^{\mathrm{T}}$ was clearly distinct, both phenotypically and ecologically, from other members of the 'Alphaproteobacteria'. Many strains belonging to the 'Sphingomonadales', Rhodospirillales and 'Rhizobiales' contain photosynthetic pigments, but strain GW $14-5^{\mathrm{T}}$ does not. It does not associate with plant roots, in contrast to Mesorhizobium loti. It has a relatively low DNA G $+\mathrm{C}$ ratio similar to Rickettsia prowazekii (Weiss \& Moulder, 1984) but does not require a host organism. The major fatty acid of members of the 'Alphaproteobacteria', such as Parvularcula bermudensis (Cho \& Giovannoni, 2003), Parvibaculum lavamentivorans (Schleheck et al., 2004), Roseobacter litoralis (Labrenz et al., 1999), Phyllobacterium myrsinacearum (Mergaert et al., 


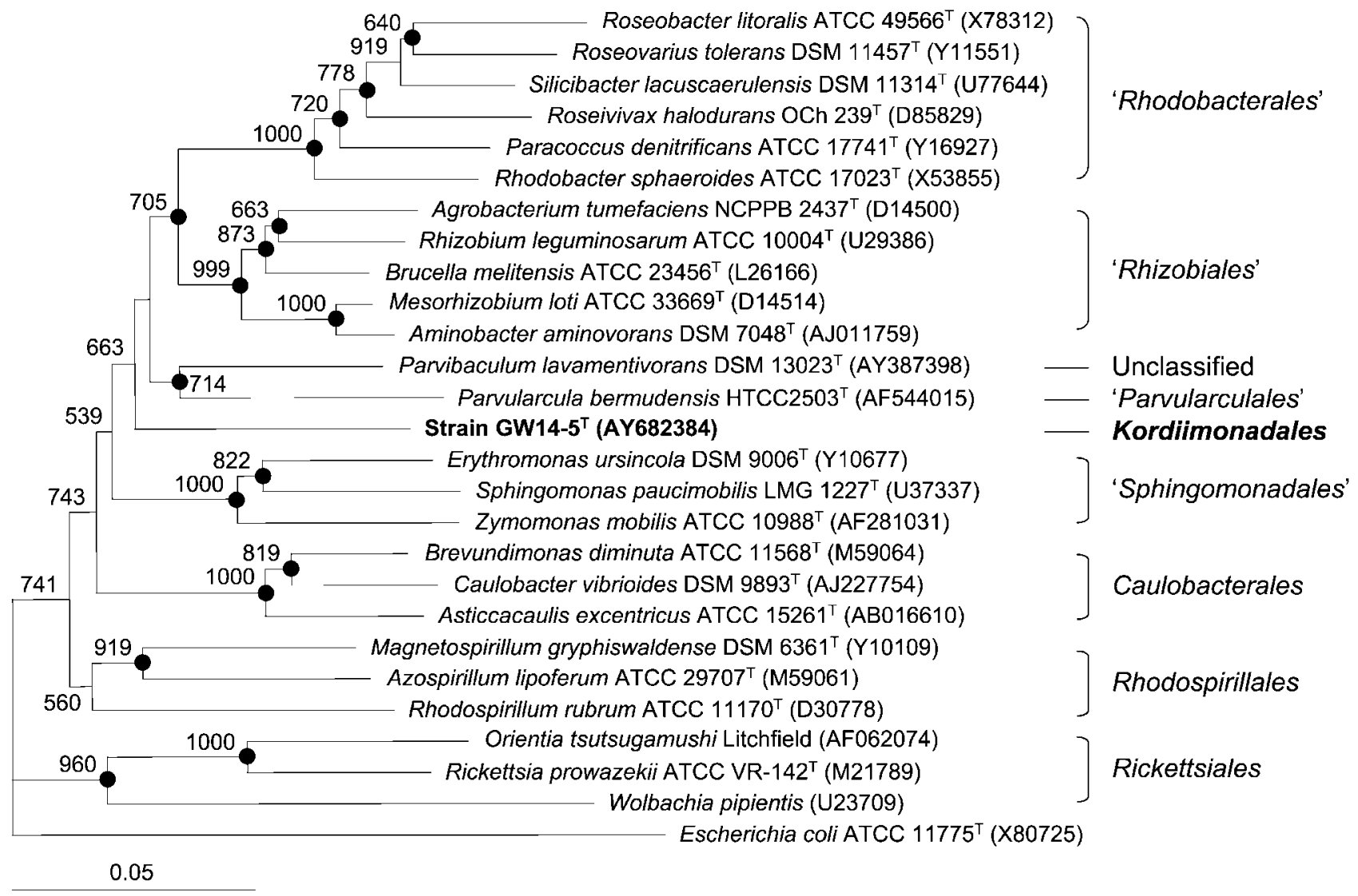

Fig. 2. Rooted neighbour-joining tree based on nearly complete $16 \mathrm{~S}$ rRNA gene sequences (1261 unambiguously aligned bases) showing relationships between strain $\mathrm{GW} 14-5^{\top}$ and representatives of the 'Alphaproteobacteria'. Bootstrap values $>50 \%$ of 1000 resamples are shown. Closed circles at nodes indicate recovered nodes with $>50 \%$ bootstrap value in a maximum-parsimony tree. Bar, 0.05 nucleotide substitutions per nucleotide position.

2002), Paracoccus haeundensis (Lee et al., 2004) and Novosphingobium pentaromativorans (Sohn et al., 2004), is octadecenoic acid (18:1) (Table 2). That of strain GW14$1^{\mathrm{T}}$ is iso-heptadecenoic acid (i-17:1).

The results of our morphological, physiological and chemotaxonomic investigations together with the phylogenetic analysis revealed that strain GW14- $5^{\mathrm{T}}$ is clearly distinct from other members of the 'Alphaproteobacteria'. The strain represents a novel species and genus in the 'Alphaproteobacteria', for which the name Kordiimonas gwangyangensis gen. nov., sp. nov. is proposed. The new order Kordiimonadales is proposed for the distinct phyletic line represented by the genus Kordiimonas.

\section{Description of Kordiimonadales ord. nov.}

Kordiimonadales (Kordii.mo.na.da'les. N.L. fem. n. Kordiimonas type genus of the order; - ales ending to denote an order; N.L. fem. n. Kordiimonadales the order of Kordiimonas).

The description is the same as for the genus Kordiimonas. The type genus is Kordiimonas.

\section{Description of Kordiimonas gen. nov.}

Kordiimonas (Kordii.mo' nas. N.L. fem. n. Kordia arbitrary name derived from the abbreviation KORDI, which stands for Korea Ocean Research and Development Institute; L. fem. n. monas a monad, unit; N.L. fem. n. Kordiimonas a micro-organism described by scientists working at KORDI).

Cells are Gram-negative, motile and rod-like in form with a length of $1 \cdot 3-1 \cdot 4 \mu \mathrm{m}$ and width of $0 \cdot 25 \mu \mathrm{m}$. Oxidase and catalase are produced. It is obligately aerobic and weakly halophilic. It has mesophilic characteristics for growth temperature and grows optimally at neutral $\mathrm{pH}$. The dominant fatty acids are branched. The respiratory quinone is MK-5. Phylogenetically, the genus forms the novel order Kordiimonadales of the 'Alphaproteobacteria'. The type species is Kordiimonas gwangyangensis.

\section{Description of Kordiimonas gwangyangensis sp. nov.}

Kordiimonas gwangyangensis (gwang.yang.en'sis. N.L. fem. adj. gwangyangensis from Gwangyang Bay, the geographical origin of the strain). 
In addition to the characteristics reported for the genus, the cells form tiny colonies on MA that are circular, translucent, creamy white and grow up to $2-3 \mathrm{~mm}$ in diameter after 1 week. Cells are able to grow between 17 and $44^{\circ} \mathrm{C}$ and optimally between 37 and $40{ }^{\circ} \mathrm{C}$. No growth is observed below $16^{\circ} \mathrm{C}$ or above $48^{\circ} \mathrm{C}$. Growth occurs at $\mathrm{pH} 6 \cdot 0-8 \cdot 5$ and optimally at $\mathrm{pH} 7 \cdot 0$. The optimal salt concentration for growth is $2 \%$, and the organism has difficulty growing at $\mathrm{NaCl}$ concentrations above $4 \%$ or below $0.5 \%$. It does not reduce nitrate to nitrite. The DNA G $+\mathrm{C}$ content is $39.3 \mathrm{~mol} \%$. Positive results are obtained for $\beta$-glucosidase and for the assimilation of glucose, $\mathrm{N}$-acetylglucosamine and maltose. All other tests in API 20NE were negative. Based on the Microlog system, the strain can oxidize $\alpha$-cyclodextrin, dextrin, Tweens 40 and 80, $\mathrm{N}$-acetylglucosamine, cellobiose, $\alpha$-D-glucose, maltose, D-trehalose, methyl pyruvate, $\beta$ hydroxybutyric acid, L-alanyl glycine, L-aspartic acid, L-glutamic acid, glycyl-L-glutamic acid, L-threonine, putrescine and glucose 1 -phosphate. The dominant fatty acids are i-17: $1(46 \cdot 2 \%)$, i-15:0 (15·1\%) and i-17:0 (12.6\%).

The type strain, GW14-5 $5^{\mathrm{T}} \quad\left(=\mathrm{KCCM} \quad 42021^{\mathrm{T}}=\mathrm{JCM}\right.$ $12864^{\mathrm{T}}$ ), was isolated from the sediments of Gwangyang Bay, Republic of Korea.

\section{Acknowledgements}

We are grateful to the Editor Dr J.-F. Bernardet, Dr J. Euzéby and two anonymous referees. This work was supported by the Ecotechnopia Program, Ministry of Environment, the Marine and Extreme Genome Research Center Program, Ministry of Marine Affairs and Fisheries, and the 21C Frontier Microbial Genomics and Applications Center Program, Ministry of Science \& Technology (grant MG02-0101-001-10-0), Republic of Korea.

\section{References}

Bae, S. S., Lee, J.-H. \& Kim, S.-J. (2005). Bacillus alveayuensis sp. nov., a thermophilic bacterium isolated from deep-sea sediments of the Ayu Trough. Int J Syst Evol Microbiol 55, 1211-1215.

Cho, J.-C. \& Giovannoni, S. J. (2003). Parvularcula bermudensis gen. nov., sp. nov., a marine bacterium that forms a deep branch in the Alphaproteobacteria. Int J Syst Evol Microbiol 53, 1031-1036.

Collins, M. D. (1985). Isoprenoid quinone analysis in bacterial classification and identification. In Chemical Methods in Bacterial Systematics, pp. 267-287. Edited by M. Goodfellow \& D. E. Minnikin. London: Academic Press.

Garrity, G. M. \& Holt, J. G. (2001). The road map to the Manual. In Bergey's Manual of Systematic Bacteriology, 2nd edn, vol. 1, pp. 119-166. Edited by D. R. Boone, R. W. Castenholz \& G. M. Garrity. New York: Springer.

Jordan, D. C. (1984). Genus I. Rhizobium Frank 1889, $338^{\mathrm{AL}}$. In Bergey's Manual of Systematic Bacteriology, vol. 1, pp. 235-242. Edited by N. L. Krieg \& J. G. Holt. Baltimore: Williams \& Wilkins.
Jukes, T. H. \& Cantor, C. R. (1969). Evolution of protein molecules. In Mammalian Protein Metabolism, vol. 3, pp. 21-132. Edited by H. N. Munro. New York: Academic Press.

Kocur, M. (1984). Genus Paracoccus Davis 1969, 384 ${ }^{\mathrm{AL}}$. In Bergey's Manual of Systematic Bacteriology, vol. 1, pp. 399-402. Edited by N. L. Krieg \& J. G. Holt. Baltimore: Williams \& Wilkins.

Krieg, N. R. \& Döbereiner, J. (1984). Genus Azospirillum Tarrand, Krieg and Döbereiner 1979, 79 $\mathrm{AL}$ (effective publication: Tarrand, Krieg and Döbereiner 1978, 978). In Bergey's Manual of Systematic Bacteriology, vol. 1, pp. 94-104. Edited by N. L. Krieg \& J. G. Holt. Baltimore: Williams \& Wilkins.

Labrenz, M., Collins, M. D., Lawson, P. A., Tindall, B. J., Schumann, P. \& Hirsch, P. (1999). Roseovarius tolerans gen. nov., sp. nov., a budding bacterium with variable bacteriochlorophyll $a$ production from hypersaline Ekho Lake. Int J Syst Bacteriol 49, 137-147.

Lee, J. H., Kim, Y. S., Choi, T. J., Lee, W. J. \& Kim, Y. T. (2004). Paracoccus haeundensis sp. nov., a Gram-negative, halophilic, astaxanthin-producing bacterium. Int $J$ Syst Evol Microbiol 54, 1699-1702.

Mergaert, J., Cnockaert, M. C. \& Swings, J. (2002). Phyllobacterium myrsinacearum (subjective synonym Phyllobacterium rubiacearum) emend. Int J Syst Evol Microbiol 52, 1821-1823.

Poindexter, J. S. (1989). Genus Caulobacter Henrici and Johnson 1935, 83 ${ }^{\mathrm{AL}}$. In Bergey's Manual of Systematic Bacteriology, vol. 3, pp. 1924-1939. Edited by J. T. Staley, M. P. Bryant, N. Pfennig \& J. G. Holt. Baltimore: Williams \& Wilkins.

Saitou, N. \& Nei, M. (1987). The neighbor-joining method: a new method for reconstructing phylogenetic trees. Mol Biol Evol 4, 406-425.

Schleheck, D., Tindall, B. J., Rossello-Mora, R. \& Cook, A. M. (2004). Parvibaculum lavamentivorans gen. nov., sp. nov., a novel heterotroph that initiates catabolism of linear alkylbenzenesulfonate. Int J Syst Evol Microbiol 54, 1489-1497.

Skerman, V. B. D. (1967). A Guide to the Identification of the Genera of Bacteria. Baltimore: Williams \& Wilkins.

Sohn, J. H., Kwon, K. K., Kang, J.-H., Jung, H.-B. \& Kim, S.-J. (2004). Novosphingobium pentaromativorans sp. nov., a highmolecular-mass polycyclic aromatic hydrocarbon-degrading bacterium isolated from estuarine sediment. Int J Syst Evol Microbiol 54, 1483-1487.

Stackebrandt, E. \& Liesack, W. (1993). Nucleic acids and classification. In Handbook of New Bacterial Systematics, pp. 158-160. Edited by M. Goodfellow \& A. G. O'Donnell. London: Academic Press.

Swings, J. \& De Ley, J. (1984). Genus Zymomonas Kluyver and van Niel, 1936, 399 AL. In Bergey's Manual of Systematic Bacteriology, vol. 1, pp. 576-580. Edited by N. L. Krieg \& J. G. Holt. Baltimore: Williams \& Wilkins.

Weiss, E. \& Moulder, J. W. (1984). Genus I. Rickettsia da RochaLima 1916, 567 ${ }^{\mathrm{AL}}$ (Nom. gen. cons. Opin. 19, Jud. Comm. 1958, 158). In Bergey's Manual of Systematic Bacteriology, vol. 1, pp. 688698. Edited by N. L. Krieg \& J. G. Holt. Baltimore: Williams \& Wilkins.

Zhang, Y., Zhu, Y.-X., Kwon, K. K., Park, J. H. \& Kim, S.-J. (2004). Novel method for determining pyrene biodegradation using synchronous fluorimetry. Chemosphere 55, 389-394. 